\title{
The Coolness of Capitalism Today
}

\author{
Jim McGuigan
}

\author{
Loughborough University, UK. j.t.mcguigan@lboro.ac.uk
}

\begin{abstract}
This paper is about the reconciliation of cultural analysis with political economy in Marxist-inspired research on communications. It traces how these two traditions became separated with the development of a one-dimensional and consumerist cultural studies, on the one-hand, and a more classically Marxist political economy of communications, on the other hand, that was accused of holding a simplistic and erroneous concept of ideology. The paper defends a conception of ideology as distorted communication motivated by unequal power relations and sketches a multidimensional mode of cultural analysis that takes account of the moments of production, consumption and textual meaning in the circulation of communications and culture. In accordance with this framework of analysis, the cool-capitalism thesis is outlined and illustrated with reference to Apple, the 'cool' corporation. And, the all-purpose mobile communication device is selected as a key and urgent focus of attention for research on commodity fetishism and labour exploitation on a global scale today.
\end{abstract}

Keywords: all-purpose communication device, capitalism, cool, cultural analysis, distorted communication, ideology, multidimensional analysis, neoliberalism, political economy

Thanks to Dave Elder-Vass for referring me to 'a sociology of Steve Jobs'

\section{It's not just cheap labor}

The iPhone is assembled in China by Foxconn, the largest electronics assembler in the world. US executives say they cannot function without companies like Foxconn. The Taiwanese company has a million workers, many willing to live in company dorms, work midnight shifts and spend 12 hours in a factory, six days a week. Chinese workers are cheaper than their American counterparts - but just as important, they are more flexible and plentiful, and thousands can be hired overnight.

(Charles Duhigg and Keith Bradshaw 2012, 4)

\section{Introduction}

In the study of communications and culture there are various different traditions of research. They may be incommensurate with one another or, alternatively, there may be grounds for synthesis between different schools of thought. Compatibility is especially difficult to achieve with regard to theorising and analysing the relation of political and economic factors to the determination of meaning. In the Marxist tradition, this has been a focal point of controversy and has resulted in schismatic lines of development. For researchers keen to avoid the kind of economic reductionism that once seemed to characterise Marxism, there has been a tendency to over-emphasise cultural autonomy and ideological determinacy in communications.

This paper argues that the most satisfactory mode of cultural analysis in critical communication studies is multidimensional. That is, amongst other things, it takes account of the interaction between cultural-ideological and economic-political factors. However, critical multidimensionality does not so much present an alternative to economic reductionism of a Marxist kind today but instead it is obliged to challenge the ideological dominance of technological determinism. This is most notable and urgent with regard to the role of 'new media' and the significance of personalised and mobile communications in culture and society now.

\section{Cultural Analysis and Political Economy}

From the 1970s a split occurred between two traditions of Marxist-inspired communications research in Anglophone scholarship, in effect, between cultural analysis on the one hand and political economy on the other. The particular tradition of cultural analysis under consideration here, which 
had many precursors, became associated very largely at this time with the work of the Birmingham Centre for Contemporary Cultural Studies under the leadership of Stuart Hall. The tradition of political economy under consideration was associated most strongly with the work of Herbert Schiller and his associates in North America and, in Britain, with the work of Nicholas Garnham, Peter Golding and Graham Murdock; not so much with the Frankfurt School tradition of critical theory (see, for example, Murdock \& Golding, 1973) ${ }^{1}$. It is unnecessary to rehearse here the key themes in the work of these critical communications' scholars. However, it is necessary to indicate, albeit briefly, why the cultural studies' tradition became separated from the political economy of communications so sharply in the 1980s.

The separation had already been signalled as early as the 1950s by Raymond Williams, the most important founding figure of what came to be known as "British Cultural Studies" (Turner 2003). Commenting on the kind of Marxist writings on culture that had flourished to some extent in Britain during the 1930s, Williams (1963 [1958], 272-273) remarked in exasperation twenty years later, 'To describe English life, thought, and imagination in the last three hundred years simply as "bourgeois", to describe English culture now as "dying" [as Christopher Caudwell had indeed done in the 1930s], is to surrender reality to a formula'. Williams himself recognised that many Marxists were unhappy with such simplistic and windy rhetoric. Yet, even the more sophisticated Marxist ways of making sense of culture and society known to Williams at the time still left him perplexed as to the truth of the matter:

Either the arts are passively dependent on social reality, a proposition that I take to be that of mechanical materialism, or a vulgar misinterpretation of Marx. Or the arts, as the creators of consciousness, determine social reality, the proposition which the Romantic poets sometimes advanced. Or, finally, the arts, while ultimately dependent, with everything else, on the real economic structure, operate in part to reflect this structure and its consequent reality, and in part, by affecting attitudes towards reality, to help or hinder the constant business of changing it. I find Marxist theories of culture confused because they seem to me, on different occasions and in different writers, to make use of all these propositions as the need serves (Williams1963 [1958], 266-267).

Not unusually, of course, the complaint here is not so much against Karl Marx or Friedrich Engels (in fact, they are quoted favorably by Williams in 1958) as it is against Marxists. Still, it did make Williams think at the time that he needed to look beyond the Marxist tradition in order to develop his own theorising. When he did eventually get around to naming his distinctive theoretical position as "cultural materialism" (Williams 1981), though, Williams certainly saw it as broadly Marxist (see Williams 1977). Yet, by then - the 1980s - Williams was no longer the leading light of 'British Cultural Studies'. Stuart Hall had become the chief spokesperson for this newly popular field of study. Hall (1986 [1980]) asserted in his paper 'Cultural Studies - Two Paradigms' that 'the names of the game' in the field were 'culturalism' and 'structuralism'; and he gave short shrift indeed to

...the attempt to return to the terms of a more classical 'political economy' of culture. This position argues that the concentration on the cultural and ideological aspects have been wildly over-done. It would restore the older terms of 'base/superstructure', finding in the lastinstance determination of the cultural-ideological by the economic, the hierarchy of determinations which both alternatives [culturalism and structuralism] appear to lack. This position insists that economic processes and structures of cultural production are more significant than their cultural-ideological aspect: and that these are quite adequately caught in the more

\footnotetext{
${ }^{1}$ Interestingly, the Frankfurt School of critical theory that coined the term 'culture industry' (Adorno and Horkheimer 1979 [1944]) and inspired a great deal of critical communications research was more interested in the ideology critique of capitalist culture than the political economy of capitalism and, in this respect, had an affinity with 'the Birmingham School' of cultural studies, as Douglas Kellner (1997) has noted.
} 
classical terminology of profit, exploitation, surplus-value and the analysis of culture as commodity. It retains a notion of ideology as 'false consciousness' (Hall 1986 [1980], 46-47).

Hall may well have been right to complain about the undervaluing of the determinacy of the cultural-ideological - that is, the problem of meaning, which was too easily treated as 'false consciousness' - by the political economy of communications perspective. Yet, it was extremely unfortunate to have exiled terms like 'profit', 'exploitation' and 'surplus-value' from Marxist-inspired cultural analysis. Without an acknowledgement of them, cultural analysis would hardly be Marxist. It might well be something else. At that time, however, Hall probably did not intend to dispense entirely with Marxism if at all. Yet, he did, perhaps unwittingly, open the way for other exponents of 'British Cultural Studies' effectively to do so.

For Hall, the question of ideology was crucial to the study of communications so how it was defined really mattered. His concept was focused upon signification, "ideological power: the power to signify events in a particular way" (Hall 1982, 69). In this respect, Hall was very much influenced by structural linguistics and how it could explain "the reality effect" of signification. He also drew upon the early Soviet linguist Volosinov's notion of the "class struggle in language" and the multiaccentuality of the sign, which was similar to Umberto Eco's emphasis on polysemy. Hall's (1997 [1974]) own encoding/decoding model of television discourse had already placed great stress on differential interpretations of meaning. Encoding/decoding had affinities with the uses and gratifications school of communications research, which also assumed an audience actively appropriating and making sense of media messages for its own purposes at the point of consumption. Inevitably, this way of thinking raised questions concerning just how active was the audience. For Hall and his closest followers, audience activity was motivated socially in relation to class, gender and ethnicity. For others, agency was played up much further, not only in media study but also in subcultural research. John Fiske $(1989,37)$, for instance, took this conception of the active audience/consumer in what was becoming an uncritical populist strand of Cultural Studies to an absurd extreme, at one point even comparing young people's pilfering of clothes in a shopping mall to the tactics of the Vietcong. At this absurd extreme, then, shopping had indeed become a revolutionary act. It was an absurdity that was gleefully derided by more economic-minded critics of communications and culture (see McGuigan 1992).

Stuart Hall himself never went to such lengths yet much of his work is quite evidently premised upon an avoidance of economic reductionism and, in consequence, there is a tendency to neglect economic factors and to exaggerate the role of ideology ${ }^{2}$. In this respect, he was drawn to the work of Louis Althusser on ideology and Antonio Gramsci on hegemony. His dismissal of a caricatured concept of ideology as 'false consciousness', very much inspired by Althusserianism, begs a great many questions. It is reasonable to argue as Hall, Althusser and Gramsci have all done in their various ways that ideological power does not just reside in ideas but is inscribed in taken-forgranted practices and customary routines. Also, it is quite reasonable to assume that ideological assumptions are not wholly mistaken, that they have within them elements of truth or truthfulness. Otherwise, their appeal would be much weakened. However, it is not strictly necessary to dispense with the critical force of a concept of ideology as distorted communications, which is a rather more complex notion than 'false consciousness'. Although Hall - at least in his writings on ideology in the

\footnotetext{
${ }^{2}$ Hall himself never actually denied the importance of economic factors in his path-breaking work on law and order (Hall et al, 1978) and authoritarian populism/Thatcherism (Hall and Jacques 1983; Hall 1988), though political and ideological factors tended to be emphasised rather more in such work. The later 'New Times' thesis (Hall and Jacques 1989) however, was obliged to take account of epochal transformation in political economy with the advent of neoliberalism and in the light of historical setbacks for socialism. And, in an interview with Laurie Taylor, whilst admitting a certain disillusion and bafflement with contemporary politics, Hall insisted, 'I am still a Marxist in terms of what Marx says about capital. Capital remains an incredibly revolutionary force. It has transformed our lives. We are now seeing yet another globalisation to create the world as a market for capital. This is about the seventh attempt. We've had all kinds of globalisations: imperial colonisation, Cold War American hegemony. Now Blair [still British PM at the time of the interview] aspires that capitalists should provide healthcare for my grandchild, that Barclays or Tesco should run my school. It's an astonishing aspiration. It only happens when capital becomes such a huge global force' (Hall \& Taylor, 2006: 16-17).
} 
1980s - retains the sense that ideology frames reality to serve the interests of the powerful (thereby, remaining largely in line with the dominant ideology thesis), he tends to evade proper consideration of a process of distortion when he actually critiques the claims of the powerful. Marx (1976 [1867], 163-164), however, did stress this aspect of distortion not only in denouncing dominant ideology but also when he described the process of commodity fetishism, which I take to be an ideological effect:

A commodity appears at first sight an extremely obvious, trivial thing. But its analysis brings out that it is a very strange thing, abounding in metaphysical subtleties and theological niceties. So far as it is a use-value, there is nothing mysterious about it, whether we consider it from the point of view that by its properties it satisfies human needs, or that it first takes on these properties as the product of human labour. It is absolutely clear that, by his activity, man changes the forms of the materials of nature in such a way as to make them useful to him. The form of wood, for instance, is altered if a table is made out of it. Nevertheless the table continues to be wood, an ordinary, sensuous thing. But as soon as it emerges as a commodity, it changes into a thing that transcends sensuousness. It not only stands with its feet on the ground, but, in relation to all other commodities, it stands on its head, and evolves out of its wooden brain grotesque ideas, far more wonderful than if it were to begin dancing of its own free will.

For a cultural analyst now, that famous passage from Marx is especially pertinent when there is such a proliferation of heavily fetishised albeit useful communications gadgetry in everyday life that is not only at the hub of meaning in circulation but also of capital accumulation today, constituting a key nexus of ideology and economy.

So-called 'post-Marxists' today are not only keen to avoid the taint of economic reductionism; they also prefer to risk sliding into relativism by adopting a conventionalist position in epistemology instead of pursuing a critical-realist interrogation of ideology whereby they might be required to distinguish between truth and falsehood. This is the case with J.B. Thompson (1990) who, nevertheless, provides an exceptionally useful heuristic typology of different modes of ideological representation (legitimation, dissimulation, unification, fragmentation and reification) each with its associated strategies of symbolic construction (such as displacement and euphemisation for dissimulation) that I have borrowed and applied in my own research on the Millennium Dome fiasco (McGuigan 2003).

\section{Multidimensional Analysis}

Since the 1980s, Cultural Studies has developed along several different trajectories to the extent that it is no longer possible to isolate a mainstream position with a discernible consensus around it except to note that it probably is no longer especially Marxist in any recognisable sense (see my account of the subsequent history in McGuigan, 2006 and updated in McGuigan, 2010a). It also ceased to be 'British Cultural Studies'. Following the election of Margaret Thatcher in 1979 and during the early phase of the neoliberal counter-revolution (that is, to Williams's (2011 [1961] "Iong revolution") that was underway in Britain from the 1980s, as an indication of the way things were going, a number of British exponents of Cultural Studies went to Australia, including John Fiske and Tony Bennett. Then, Bennett (1998) set about the construction of a Foucauldian and managerialist school of Cultural Policy Studies. Eventually, there was a North American takeover, especially signalled by the editorial control of the journal Cultural Studies moving to the USA under the command of Lawrence Grossberg. Fiske also moved to the USA. And, by the mid-2000s, it was possible to publish an anthology of work purporting to go beyond the American takeover to represent the thoroughgoing 'internationalisation' of Cultural Studies (Abbas and Erni 2005). Nevertheless, the Marxist dispute with the legacy of Hallian (Birmingham School) Cultural Studies continued, particularly with the alternative emergence of a multidimensional framework of analysis adopted by 
some scholars ${ }^{3}$ that was curiously enough not so very different from Stuart Hall's and Richard Johnson's (1979) own earlier thinking about the shape of the field.

My own developed critique of "cultural populism" in Cultural Studies (McGuigan 1992, 1997, $2006,2011)$ focuses upon two problematic issues: first, the ontological inadequacy of its onedimensional methodology; second, its coalescence with neoliberal ideology. Cultural Studies from and inspired by the Birmingham School concentrated almost exclusively upon consumption by the end of the 1980s and left an extremely dubious legacy for education and research that spent much time and effort over subsequent years simply tracking and celebrating the pleasures of masspopular consumption. Very little analytical work was done on production, either with regard to the labour process involved in making cultural products or in respect of the political economy of the media and cultural industries - that is, capitalist media and cultural industries. Moreover, textual analysis was qualified excessively by variants of reader-response theory and 'ethnographic' audience research that was often of a slight and superficial character. Hall's 'preferred reading' that was said to be encoded ideologically into media texts seemed to count for little in the face of freewheeling popular interpretation and creative use of cultural products by active audiences and consumers. Such methodology could not possibly account for the ontological complexity of culture in circulation. It could not explain how and why we get the communication and cultural products that we do. Only some kind of multidimensional analysis that takes account of both ideological and economic factors from production to consumption could do so satisfactorily (see, for example, Kellner 1997 on production, text and consumption).

Consumptionist Cultural Studies attributed an inordinate measure of agency to the consuming subject and, now with the advent of interactive, social-networking media, to the producerly consumer, reminiscent of Roland Barthes's (1977 [1968]) "birth of the reader", a figure that was already there in the active audience. These hyperactive consumers, shoppers, readers, listeners, viewers, spectators, cybersurfers and, latterly, citizen journalists, bloggers and so on bear a striking resemblance to the sovereign consumer of neoclassical economics, the core ideological assumption of neoliberal, "free-market" capitalism. The customer as king or queen is the endlessly repeated mantra of neoliberalism, as though giant corporations were really beholden to the whims and wishes of ordinary people rather than the masters of the Universe. In order to dictate supply, it should be appreciated, the sovereign consumer must already be fully aware of what he or she wants and be able to imagine exactly what can be supplied as well. Ordinary people rarely if at all, to put it mildly, have access to such knowledge; nobody does. It is the producers who come up with the stuff and cultivate the tastes and habits of consumers. Yet, neoliberalism insists upon flattering our vanity as it picks our pockets. Even if the sovereign consumer was as all-knowledgeable as free-market 'theory' presumes, only a very small number of such luminaries would actually be in possession of enough money in any case to buy whatever they want.

It is perfectly reasonable to reject the view of ordinary people that may have been held by some left-wing critics in the past as passive dopes overwhelmed by the lure of consumerism and the distortions of the media. It is also reasonable to doubt elitist assumptions concerning cultural value and have a more nuanced and discriminatory appreciation of mass-popular culture. These straw Marxists and their allegedly simplistic beliefs are easily dismissed as irrelevant. However, consumerist Cultural Studies and what I have called 'cultural populism' simply inverted those assumptions and merely asserted the exact opposite virtually without qualification, thereby losing sight of the sheer power both economically and ideologically of capital.

\footnotetext{
${ }^{3}$ A good example of a developed multidimensional analysis of communications and culture is Toby Miller and his coauthors' $(2001,2005)$ "global Hollywood" research, which grew out of a dissatisfaction with much film/screen studies and its exclusively textual orientation. An important concept derived from this work is the new international division of cultural labour (NICL).
} 


\section{Cool Capitalism}

In the aftermath of the seemingly uninterrupted crisis of the past few years that erupted in 20078 there has been some fundamental questioning of the capitalist system and exploration of alternatives to it (such as Harvey 2010; McChesney and Foster 2010; Wright 2010). Yet there are still many serious critics of capitalism who treat its persistence as an unsurpassable given (for instance, Gamble, 2009). The legitimacy of capitalism as a civilisation remains strong, according to the 'realists' whose conventional wisdom spreads from Right to the Left across the political spectrum, even when its mode of production is faced with systemic collapse. This is, no doubt, at least partly attributable to the relatively parlous condition of the international Left, its confidence and indeed very existence shattered and nearly destroyed over the past thirty years. There are, however, promising signs of not just critical but practical rebirth in the rhizome laid down by the global justice movement from the turn of the Millennium, the advance of social democracy through the 2000s in South America, recent manifestations of the Occupy movement and growing labour unrest around the world.

Not so very long ago, the legitimacy of capitalism was constantly in doubt: its justification was called into question repeatedly. Critics pointed to the internal contradictions of capitalist political economy, recurrent crises of over-production, loss of conviction in dominant ideology, faulty apparatuses of ideological reproduction, cultural challenges to the hegemonic fashioning of "reality", outbreaks of class struggle and innumerable sites of political contestation, including feminist, gay and anti-racist campaigns. Now, radical political culture is much quieter if not exactly silent and the questioning of capitalism's legitimacy muttered only perhaps in jest. Why should such questioning appear to be unspeakable in contemporary discourse, if heard seriously at all in the public sphere, sounding nostalgic and distinctly passé? Is it really beyond our imaginative capacity to countenance an alternative? What imaginary prevents it?

The cardinal question that should concern us is not, however, only to do with explaining the diminution of criticism and opposition. Nor is it the big one, how does capitalism persist? But, rather, less ambitiously, how is capitalism justified? Admittedly, it would be mistaken to assume that capitalism's existence is accounted for by its ideological legitimisation alone. It is too deeply entrenched materially and institutionally - that is, systemically - to be propped up simply by ideas. Yet, Luc Boltanski and Eve Chiapello, (2005 [1999]) are right to argue that capitalism in its various phases has to be justified. There has to be some compelling justification and, indeed, sense of justice closely associated with it. Boltanski and Chiapello are also onto something when they suggest that the most efficient justification for a set of societal arrangements that contributes to its renewal and sustenance derives, paradoxically, from the appropriation of criticism. This insight may be counterintuitive, though it is not difficult to note historical instances of the same, the stealing of the opposition's clothing, for instance, that was attributed to Disraeli in the nineteenth century. Just think of the role of socialism in the reconstruction and restoration of capitalism in the mid-twentieth century.

Boltanski and Chiapello distinguish between the artistic critique and the social critique of capitalism. These two forms of critique draw upon quite different sources of indignation. The social critique is indignant at the poverty and inequality associated with capitalism; and also challenges the opportunistic and egoistic values fostered by capitalism. These criticisms of capitalist civilisation have been heard much less since the 1970s. On the other hand, however, the artistic critique's indignation at disenchanting and inauthentic features of capitalism that are combined with a generalised sense of oppression has had greater resonance during the same period. Demands for autonomy, liberation, authenticity and singularity - values associated with May ' 68 and all that - have indeed been heard and, moreover, apparently integrated into the system. This 'new spirit of capitalism' is very different from the asceticism of Max Weber's Protestant ethic that was supposed to have been the original value system of a rational and robust capitalism. The new spirit is characterised by the project-orientation of portfolio workers, which is a key feature of the managerial and networking mentality that is promoted by the voluminous literature coming out of business schools.

Capitalism may be an absurd system, as Boltanski and Chiapello argue, founded upon outrageous exploitation and manifestly destructive as well as creative, but few doubt its validity whatever the social and personal cost. How, then, is it justified so effectively? Ideological hegemony is not 
only obtained at the philosophical level (assuming that the free-market economics propounded by business schools, corporate expertise and mainstream news media deserve to be categorised as such) but also - and necessarily - in terms of cultivating popular consent. Adherence to capitalism does not result, most significantly, from reasoned agreement with the supposed truths of freemarket economics and recognition of the deficiencies of socialist planning and commandmanagement economics but much more importantly, instead, by misrecognition and imaginative construction at a mundane level, consonant with both the dull as well as the flashy routines of a capitalistic way of life.

The aim of the cool capitalism thesis that is outlined below, then, is to at least partly account for how latter-day, that is, neoliberal capitalism has constructed popular legitimacy of such a resilient kind that it goes beyond management ideology and propaganda into the texture and common sense of everyday life in spite of severe and recurrent economic crisis; and, indeed, worsening ecological conditions in the world today - all of which directly affects people's lives.

The basic definition of cool capitalism is the incorporation of disaffection into capitalism itself. It is, in Erving Goffman's (1971 [1959]) sense, a "front region" that is seductively tasteful in its appeal to populations at large, both the comparatively affluent and, indeed, the aspirant poor. There is, however, a "back region", rather like an industrialised kitchen with dirty secrets that do not meet health and safety standards. This back region is occasionally glimpsed and, in consequence, the fare on offer is called into question by troubled voices. Like in any good restaurant, the maitre d' must somehow cool out the customers who might otherwise take their custom elsewhere. Maybe it is 'cool' to have a filthy kitchen and, in any event, you have to smash eggs in order to make an omelette; and sometimes they spill onto the floor where the rats hang out.

It is hardly necessary to point out how ubiquitously the word "cool" is used presently around the Earth; or, just as important, how widely embedded is the sensibility associated with that term whether the word is actually used or not. It is everywhere. Coolness is not some marginal or dissident trend. It is at the heart of mainstream culture insofar as we can speak of such a phenomenon at all.

In my book Cool Capitalism (McGuigan 2009), several examples of present-day coolness are given, particularly in commerce. The genealogy of the word and the discourses through which it has passed are also traced. 'Cool' derives from West African itutu, the core meaning of which refers to composure in the heat of battle. Although it was closely associated with masculinity in origin, this may not have been exclusively so and, in any case, it is not exclusively so today. The American art historian, Robert Farris Thompson (1974, 1976 [1971]) has documented the aesthetics of itutu in the West and the South of Africa, its passage to the Americas with the slave trade and the formation of a cool culture of disaffection on the margins of US society. Generally speaking, coolness became a personal stance, mode of deportment and argot, associated with dignity under pressure in oppressive circumstances. It is a distinctive feature of 'Black Atlantic' culture (Gilroy, 1993) and it also became extremely prominent and attractive to others, including whites, especially through mid-twentieth century jazz culture.

Although coolness is difficult to pin down - and deliberately so - Pountain and Robins (2000) have, nevertheless, sought to identify three essential traits of the cool persona: narcissism, ironic detachment and hedonism. It is easy to call up plenty of sub-cultural examples over the years, either indirectly or directly related to black culture, from, say, Parisian existentialism to latter-day hiphop culture. Very recently, an article in a philosophy magazine that was unusually on sale on the mass market celebrated coolness as a 'fusion of submission and subversion'. From this point of view, the cool person, albeit perpetually alienated, conducts a creative balancing act. The would-be philosopher in question obviously thinks coolness is still cool. Some black American commentators don't.

Social psychologists Richard Majors and Janet Mancini Billson (1993 [1992], xi) remarked several years ago in their empirical study of black masculinity in urban locales, "coolness may be a survival strategy that has cost the black male - and society - an enormous price". Whilst it represents black identity and pride in the ghetto such 'compulsive masculinity' in that context is also 
seriously damaging to both women and men, not to mention the druggy lifestyle, disorganised sociality and violent criminality - which is by no means confined to working-class black males in the USA.

Cool today is not only about black American culture; it is global and colourless. The sign floats free. And, key to the cool capitalism thesis, 'cool' has traversed the political landscape, roughly speaking, from the Left to the Right. It is now more a sign of compliance than of resistance.

This argument is substantiated by Thomas Frank's (1997) research on "the conquest of cool" in which he claims that cool sensibility caught on in the American mainstream as long ago as the 1950 s with the rise of rebels without a cause, rejecting the staid conformity fostered by postSecond World War organised capitalism in middle-class life and business. Nowadays, of course, nearly every management consultant you meet plays blues guitar. According to Frank, the counter culture caught on very rapidly in corporate America. Cool pose and the buzzword, 'creativity' are now de rigeur in managerial ideology. And, as a couple of Swedish management theorists have pointed out, business today is "funky" (Ridderstrale and Nordstrom 2002 [2000]).

It is interesting that Frank confined his research on 'cool' business and management discourse to the USA while Boltanski and Chiapello restricted their research to France. Yet, even French management texts are influenced by 'Anglo-Saxon' neoliberal thought and, indeed, Gallic cadres read American management books. Cool capitalism is now a global phenomenon with albeit American roots, though by no means restricted to the USA. It is indisputably a feature of 'Americanisation' but Americanisation, it has to be said, is only part of the story and too simple a way of understanding cool capitalism's presence in the world at large.

In their different ways, Boltanski and Chiapello's "new spirit of capitalism" and Frank's "conquest of cool" stress the role of managerial ideology in the organisational and cultural changes wrought by the neoliberal transformation of culture and society. Yet, the most evident site of "cool capitalism" in everyday life is consumer culture and the representation of "cool" commodities. This has been especially notable in the clothing industry addressed to the young with companies like The Gap and Nike drawing upon countercultural themes and symbolisation with their "rebel" gear. However, the coolest of all commodities today is the all-purpose mobile communication device, that is, on-line mobile phones and tablets, which is the subject of the next section. However, it should be emphasised that multidimensional analysis of culture in circulation involves textual analysis (see McGuigan 2008 and 2010a) and research into the labour process of production (see McGuigan $2010 \mathrm{~b}$ and 2012 forthcoming) as well as the political economy and ideology of "cool" corporations.

\section{The All-Purpose Mobile Communication Device}

The all-purpose mobile communication device (apmcd) represents an ideal focus for critical communication studies today and constitutes a perfect test case for multidimensional analysis from a broadly Marxist perspective and, perhaps also, for the cool-capitalism thesis. The issues at stake are numerous and far-ranging.

In order to make sense of the significance of the apmcd in contemporary culture and society, it is necessary, first and foremost, to confront the old chestnut of technological determinism. The classical critique of technological determinism in communications was made by Raymond Williams (1974) in the 1970s and developed further by Brian Winston (1995 [1990], 1996) in the 1990s. It is unnecessary to rehearse those criticisms here (see my explication in McGuigan 2007). Suffice it to say that Williams stressed the importance of intention in technological innovation, that there always has to be a social motivation for investment, research and application in product development. In the original test case of television, Williams also linked technological development to the phenomenon of mobile privatisation that emerged historically with mass migration and urban industrialism. On-line mobile phones, laptops and tablets are exactly the kind of technological gadgetry that is functional to a yet more mobile and privatised way of life under conditions of late-modernity. They 
are extolled as such persistently in advertising and, more generally, in the technologically determinist propaganda that is a prominent feature of neoliberal political economy.

Still, however, technological-determinist explanation in relation to politics is a temptation even for the shrewdest of critics today. Take, for instance, the British journalist Paul Mason's (2012) account of the 2011 eruption of democratic protest around the world, Why It's Kicking Off Everywhere - The New Global Revolutions. Recalling a debate he had with radical students in London, Mason (2012, 2) remarks, "is it the technology, the economics, the mass psychology or just the zeitgeist that's caused this global explosion of revolt? I inclined to a technological-determinist explanation". He enthuses about the social networking through Facebook and Twitter that contributed to mobilising protesters in Tunisia and Egypt. 'It's the network', blurts Mason, thereby also echoing Manuel Castells's (1996) largely technological-determinist take on the social impact of computer-mediated communications - emergence of "the network paradigm" - nearly twenty years ago. Yet within a page, Mason $(2012,3)$ was to somewhat contradict his own self-styled technological determinism:

We're in the middle of a revolution caused by the near collapse of free-market capitalism combined with an upswing in technical innovation, a surge in desire for individual freedom and a change in human consciousness about what freedom means. An economic crisis is making the powerful look powerless, while the powerless are forced to adopt tactics that were once the preserve of niche protest groups.

Surely that passage suggests that the principal determination of democratic protest in 2011 was the economic crisis and, not unconnected to it, failed corrective policy measures, including the punishment meted out to ordinary people for the misdemeanours of finance capital. Other factors noted by Mason include "desire for individual freedom and a change in human consciousness" (which is actually a proposition about a cultural phenomenon rather than a technological phenomenon as such). Undoubtedly, digital and mobile technologies of communication and socially-embedded patterns of use among the young facilitated the mobilisation of bodies and the flow of messages from these communicative networks through the sluicegate of the international public sphere, thus appearing in amplified form in the publicity arena of "old media" like television. "New media" played their part, as did older media of, say, print or, further back, word-of-mouth in the past history of popular protest and indeed revolutionary upsurge. There is no need, therefore, to fetishise "new media" as the sole cause of recent events since they surely are not. Peter Golding's $(2000,171)$ distinction between Technology One and Technology Two is helpful here in clarifying what is at stake analytically:

Technology may be construed as the mechanisms by which human agency manipulates the material world. We can conceive of two forms of technological innovation. Technology One allows existing social action and process to occur more speedily, more efficiently, or conveniently (though equally possibly with negative consequences such as pollution or risk). Technology Two enables wholly new forms of activity previously impracticable or inconceivable. In essence many ICTs are more obviously Technology One than Technology Two.

This rather measured distinction, which does not deny the importance of new media technologies but, at the same time, puts into serious doubt the usual hyperbolic claims concerning their capacity to 'change the world'. Clearly, digital communication systems, their multiple applications and the endless succession and upgrading of seductive gadgets make a difference but not in splendid causal isolation from various combinations with cultural, economic, ideological and political factors. Such gadgetry and the mythology surrounding it is a salient feature of cool capitalism. Take, for instance, the Apple Corporation and the late Steve Jobs. Such 'cool' gadgets as the iPod, iPhone and iPad, useful as they undoubtedly are, nevertheless, exemplify the process of commodity fetishism and the obscuring of neoliberal capitalism's system of global exploitation. 
The celebrification and, indeed, mystification of the entrepreneurial hero has been embodied perfectly in the figure of Jobs, who, from the point of view of critical communication studies, must be treated as a textual set of signs, that is, a media construct like any other celebrity figment of the mediated imagination (see Rojek 2001 on the social construction of celebrity). Kieran Healy (2011), for instance, has sketched "a sociology of Steve Jobs" by applying Max Weber's theory of charismatic authority to the Apple CEO. Jobs has also been the subject of considerable managerial fascination as a guide to business success (Gallo 2011) and biographical attention (Moritz 2011 [2009]; Isaacson 2011), in fact, engendering a mini-publishing industry before and especially during the year of his death. His cool-dude persona and the smart gadgets that he presented to the public - though did not actually design himself - exemplify the incorporation of a certain kind of selectively constituted and apparently dissenting sensibility that is inherited from the 1960s' counter-culture whilst also making Apple the most profitable company in the world by the time of Jobs's death in October 2011.

In his sociology of Steve Jobs, Healy only mentions the manufacture of Apple products as an afterthought to his main concern with Jobs's "charisma". And, on the question of manufacture, Healy is quick to point out that Apple are not the only electronics firm that relies on a murky outsourcing and pernicious system of labour exploitation in "developing countries", most notably China. This is reminiscent of the problem with singling out Nike for special attention in the garment-industry campaign that became associated with Naomi Klein's (2000) No Logo at the turn of the Millennium in that they are not the only one. However, Nike and Apple are especially pertinent examples of the culture and political economy of transnational capitalism now since they have both cultivated a counter-cultural and rebel image that might at one time have been linked to anti-capitalism but is no longer so, thereby epitomising cool capitalism. Outsourcing the largely American corporations' digital electronics manufacture to low-pay economies where the policing of labour conditions and rights is relaxed to say the least, if existent at all, lagged behind garment manufacture but in recent years it has caught up dramatically.

In 2006, the Netherlands-based Centre for Research on Multinational Corporations (SOMO) reported on the structure of the mobile-phone industry, the network of firms along the supply chain all the way down to factories in Export Processing Zones (EPZs) or Special Economic Zones (SEZs) in places like Shenzen in Southern China (Wilde and de Haan 2006). Other research NGOs like China Labor Watch, based in New York, and Hong Kong's Students \& Scholars Against Corporate Misbehaviour (SACOM) have produced ethnographic studies of the treatment of labour in Chinese factories. Reading their reports is reminiscent of Marx's use of the governmental 'blue books' on Victorian industry in the later part of Capital Volume One.

China Labor Watch (2011) studied ten electronics factories in Guangdong and Jiangsu provinces where they interviewed over four-hundred workers in late-2010. These factories supply products for Dell, Salcomp, IBM, Ericsson, Philips, Microsoft, Apple, Hewlett Packard and Nokia amongst others. They found that excessive hours of overtime were required, the minimum wages (usually \$150-200 a month) paid did not actually cover living costs, work rates were highly intensive, tests excluded pregnant women from employment and typically formal labour contracts are either nonexistent or their provisions not actually observed in practice.

It is vital to plumb the deep structures and processes of the industry, as such research aims to do, albeit rather more descriptively than critically, in order to grasp the moment of production in the circulation of communications technology and, in consequence, meaning. Usually, general publics around the world only learn of the most extreme abuses - particularly with regard to child labour and instances of personal tragedy. A spate of suicides at the Taiwanese-owned Foxconn plants in China have been a particular focus of international attention in recent years, spurring SACOM (2011) to study where Foxconn manufactures iPods, iPhones and iPads in Shenzen, Chengdu and Chongqing. Apple was supposed to have demanded that Foxconn cleaned up its act but, as it turns out, to little or no avail, according to the Hong Kong researchers. The China Labor Watch (2011: 77) researchers from New York took a more sanguine view, arguing that, in response to criticism, 'Foxconn had become the top performer in the electronics industry' in terms of wages, by paying 
new recruits $\$ 184.80$ monthly, rising to the princely sum of $\$ 247.13$ a month after six months on the job.

In March and April 2011 SACOM interviewed one-hundred and twenty workers in Shenzen, Chengdu and Chongqing, normally young people aged between 16 and 30, approached outside the factory gates. It was found that workers are keen to do overtime because the basic wage is not enough but there is no guarantee that the overtime will actually be paid. SACOM gives an indication of the schedule of a typical day for workers at the Chengdu plant where iPads are made:

\author{
06.45 Wake up \\ 07.15 Queue up for bus \\ 07.45 Arrive at Foxconn (breakfast and punch card) \\ 08.10 Work assembly \\ 08.30 Work shift begins \\ 11.20 Lunch \\ 12.20 Work shift resumes \\ 17.20 Dinner \\ 18.20 Overtime shift begins \\ 20.20 Work shift ends \\ 21.00 Arrive at dormitory (SACOM 2011, 12).
}

Health and safety conditions are very poor at the factory in Chengdu, as they are in other Foxconn facilities. Some quotations from workers in Chengdu give a further sense of their lived experience:

"Though we produce for iPhone, I haven't got a chance to use iPhone. I believe it is fascinating and has lots of function. However, I don't think I can own one myself," a worker from Guanlan who joined Foxconn in February 2011 said.

"I never dreamed that I will buy an iPad, it may cost me two months salary. I cannot afford it. I come from a village to sell my labour at Foxconn, all I want is improve the living conditions of my family," a 24-year-old worker expressed.

"Our salary is too low compare to the selling price of an iPad. We deserve more as we generate wealth for Apple every day," an assistant to frontline supervisor in Chengdu.

(SACOM 2011, 19)

Such empirical data brings home the dirty little secret of cool capitalism, a secret that is not well concealed but nonetheless easily ignored. However, breaking the silence, The New York Times (Duhigg and Barboza 2012, a, b) has conducted a campaign of interrogation concerning Apple's operations in China. The predominant theme of such journalism in the USA, however, has been around the 'fade' in 'middle-class jobs' back home. "Middle class" is, of course, American for working class. The taken-for-granted assumption is that iPods, iPhones and iPads are manufactured in China rather than the USA because wages are much lower there. That is true but this may not be quite as significant as it appears at first sight. It has been calculated by academic economists that making iPhones in the USA would add only $\$ 65$ dollars to the price since the price of labour is such a small part of the cost of making iPhones anyway, according to the New York Times journalists, Charles Duhigg and David Barboza (2012a, 6). It is also said, to further complicate matters, that the USA does not educate enough skilled engineering operatives at an appropriate sub-degree level. Yet more seriously, though, it may be that American workers are insufficiently docile for Apple's rapid capital-accumulation strategy. Duhigg and Barboza tell the story of how Steve Jobs complained about how easily the plastic screen scratched on the iPhone prototype just before launch in 2007. He demanded that it be replaced with glass screens within six weeks. When these replacement screens eventually arrived at the assembly plant in China around midnight: 
A foreman immediately roused 8,000 workers inside the company's dormitories, according to the executive. Each employee was given a biscuit and a cup of tea, guided to a workstation and within half an hour started a 12-hour shift fitting glass screens into beveled frames. Within 96 hours, the plant was producing over 10,000 iPhones a day (Duhigg and Barboza 2012a, 2)

These extraordinary gadgets and their updates enhance the routine pleasures and everyday conveniences of the world's comparatively affluent but at a cost, the human cost of exploiting cheap labour and making life miserable for people who are prepared to work extremely hard under conditions that the world's affluent would not tolerate in order to overcome their relative poverty. A fully developed programme of Marxist analyses that explores various aspects of capitalism's cool culture, including information and communication technology as a complex social phenomenon and not just gadgetry, is vital here, tracing the economic-material and cultural-ideological nexus of communications today ${ }^{4}$. This is not to suggest that Marxism explains everything. However, Marxism's great value remains - as was also the case one-hundred-and-fifty years ago - that it asks questions which the powerful would prefer not to be asked since the answers to such questions may demystify the world we live in and yet have so little control over.

\section{References}

Abbas, Ackbar and John Nguyet Erni, eds. 2005 Internationalizing of Cultural Studies. Malden MA: Blackwell. Adorno, Theodor and Max Horkheimer. 1979 [1944]. Dialectic of Enlightenment. London: New Left Books.

Barthes, Roland. 1977 [1968]. The Death of the Author. In Image, Music, Text, edited by Stephen Heath, 142-148. London: Fontana

Bennett, Tony. 1998. Culture - A Reformer's Art. London: Sage.

Boltanski, Luc and Ève Chiapello. 2005 [1999]. The New Spirit of Capitalism. London: Verso.

Castells, Manuel. 1996. The Rise of the Network Society. Malden, MA: Blackwell.

China Labor Watch. 2011. Tragedies of Globalization - The Truth Behind Electronic Sweatshops. New York: China Labor Watch.

Duhigg, Charles and Keith Bradshaw. 2012. Where the iPhone Work Went. The New York Times Articles selected in association with The Observer, 29 January, pp1,4.

Duhigg, Charles and David Barboza, 2012a. How the US Lost Out on iPhone Work. The New York Times, 21January.

Duhigg, Charles and David Barboza, 2012b. In China, Human Costs are Built Into an iPad. The New York Times, 26 January.

Fiske, John. 1989. Understanding Popular Culture. London: Unwyn Hyman.

Frank, Thomas. 1997. The Conquest of Cool - Business Culture, Counterculture, and the Rise of Hip Consumerism, Chicago, IL: University of Chicago Press.

Gallo, Carmine. 2011. The Innovative Secrets of Steve Jobs - Insanely Different Principles for Breakthrough Success. New York: McGraw Hill.

Gamble, Andrew. 2009. The Spectre at the Feast - Capitalist Crisis and the Politics of Recession. London: Palgrave Macmillan.

Gilroy, Paul. 1993. The Black Atlantic and Double Consciousness. London: Verso.

Goffman, Erving. 1971 [1959]. The Presentation of Self in Everyday Life. Harmondsworth: Penguin.

Hall, Stuart, 1997 [1974]. The Television Discourse - Encoding and Decoding. In Studying Culture - An Introductory Reader, edited by Ann Gray and Jim McGuigan, 28-34. $2^{\text {nd }}$ edition London: Arnold.

Hall, Stuart. 1988. The Hard Road to Renewal and the Crisis of the Left. London: Verso.

Hall, Stuart. 1986 [1980]. Cultural Studies - Two Paradigms. In Media, Culture \& Society - A Critical Reader, edited by Richard Collins, James Curran, Nicholas Garnham, Paddy Scannell, Philip Schlesinger and Colin Sparks, 33-48. London: Sage.

\footnotetext{
${ }^{4}$ It would be unfortunate, however, if the kind of political economy of communications industry and technology in China that is researched by the likes Yu Hong (2008 \& 2011) were not articulated in relation to cultural analysis of the lived experiences of the labour process referred to in this article and the ideological seduction of people around the world that is critiqued by the cool-capitalism thesis.
} 
Hall, Stuart, Chas Criticher, Tony Jefferson, John Clarke and Brian Roberts. 1978. Policing the Crisis - Mugging, the State, and Law and Order. London: Macmillan.

Hall, Stuart and Martin Jacques, eds. 1983. The Politics of Thatcherism. London: Lawrence \& Wishart.

Hall, Stuart and Martin Jacques, eds. 1989. New Times - The Changing Face of Thatcherism in the 1990s. London: Lawrence \& Wishart.

Hall, Stuart and Laurie Taylor, 2006, Culture's Revenge, New Humanist, March/April, 14-17.

Harvey, David. 2010. The Enigma of Capital - And the Crises of Capitalism. London: Profile.

Healy, Kieran. 2011. A Sociology of Steve Jobs. http://kieranhealy.org/blog/archives/2011/10/10/a-sociology-of-stevejobs/ downloaded 19-01-12.

Hong, Yu. 2008. Distinctive Characteristics of China's Path of ICT Development - A Critical Analysis of Chinese Developmental Strategies in Light of the East Asian Model. International Journal of Communication 2: 456-471.

Hong, Yu, 2011. Labor, Class Formation, and China's Informationized Policy of Economic Development. Langham, MD: Lexington.

Isaacson, Walter, 2011, Steve Jobs, London: Little, Brown.

Johnson, Richard. 1979. Histories of Culture/Theories of Ideology - Notes on an Impasse. In Ideology and Cultural Production, edited by Michèle Barrett, Philip Corrigan, Annette Kuhn and Janet Wolff, 49-77. London: Croom Helm.

Kellner, Doulas. 1997. Critical Theory and Cultural Studies. In Cultural Methodologies, edited by Jim McGuigan, 12-41. London: Sage.

Klein, Naomi. 2000. No Logo - Taking Aim at the Brand Bullies. London: HarperCollins.

Majors, Richard and Janet Mancini Billson. 1993 [1992]. Cool Pose - The Dilemmas of Black Manhood in America. New York: Touchstone.

Marx, Karl. 1976 [1867]. Capital Volume 1, tr. Ben Fowkes, Harmondsworth: Penguin.

Mason, Paul. 2012. Why It's Kicking Off Everywhere - The New Global Revolutions. London: Verso.

McChesney, Robert and John Bellamy Foster. 2010. Capitalism, the Absurd System - A View from the United States. Monthly Review Press 62 (2): 1-12.

McGuigan, Jim. 1992. Cultural Populism. London: Routledge.

McGuigan, Jim. 1997. Cultural Populism Revisited. In Cultural Studies in Question, edited by Marjorie Ferguson and Peter Golding, 138-154. London: Sage.

McGuigan, Jim. 2003. The Social Construction of a Cultural Disaster - New Labour's Millennium Experience. Cultural Studies 17 (5): 669-690.

McGuigan, Jim. 2006. The Politics of Cultural Studies and Cool Capitalism. Cultural Politics 2 (2): 137-258.

McGuigan, Jim. 2007. Technological Determinism and Mobile Privatisation. In New Media Worlds - Challenges for Convergence, edited by Virginia Nightingale and Tim Dwyer, 103-117. Sydney: Oxford University Press.

McGuigan, Jim. 2008. Apprentices to Cool Capitalism. Social Semiotics 18 (3): 309-319.

McGuigan, Jim. 2009. Cool Capitalism, London: Pluto.

McGuigan, Jim. 2010a. Cultural Analysis, London: Sage.

McGuigan, Jim. 2010b. Creative Labour, Cultural Work and Individualisation, International Journal of Cultural Policy 16 (3): 323-333.

McGuigan, Jim, 2011, From Cultural Populism to Cool Capitalism. Art and the Public Sphere 1 (1): 7-18.

McGuigan, Jim. 2012 forthcoming. Cool Capitalism at Work, In The Cultural Career of Coolness, edited by Ulla Haselstein, Irmela Hijiya Kirschnereit, Catrin Gersdorf and Elena Giannoulis. Lanham, MA: Lexington Books.

Miller, Toby, Nitin Govil, John McMurria and Richard Maxwell. 2001. Global Hollywood, London: British Film Institute.

Miller,Toby, Nitin Govil, John McMurria, Richard Mazwell and Ting Wang. 2005. Global Hollywood 2. London: British Film Institute.

Moritz, Michael. 2011 [2009]. Return to the Little Kingdom - Steve Jobs, The Creation of Apple, And How it Changed the World. London: Duckworth.

Murdock, Graham and Peter Golding. 1974. For a Political Economy of Mass Communications. In The Socialist Register 1973, edited by Ralph Miliband and John Saville, 205-234. London: Merlin.'

Pountain, Dick and David Robins. 2000. Cool Rules - Anatomy of an Attitude. London: Reaktion.

Ridderstrale, Jonas and Kjell Nordstrom. 2002 [2000]. Funky Business - Talent Makes Capital Dance. London: Pearson.

Rojek, Chris. 2001. Celebrity, London: Reaktion.

Students \& Scholars Against Corporate Misbehaviour (SACOM). 2011. Foxconn and Apple Fail to Fulfil Promises - Predicaments of Workers after the Suicides. Hong Kong: SACOM.

Thompson, John B. 1990. Ideology and Modern Culture - Critical Social Theory in the Era of Mass Communication. Cambridge, MA: Polity Press.

Thompson, Robert Farris. 1974. African Art in Motion. Berkeley \& Los Angeles, CA: University of California Press.

Thompson, Robert Farris, 1976 [1971]. Black Gods and Kings. Bloomington, IN: Indiana University Press. 
Turner, Graeme. 2003. British Cultural Studies - An Introduction. London: Routledge.

Wilde, Joseph and Esther de Haan. 2006. The High Cost of Calling - Critical Issues in the Mobile Phone Industry, Amsterdam: Centre for Research on Multinational Corporations (SOMO).

Williams, Raymond, 1963 [1958], Culture and Society 1780-1950. Harmondsworth: Penguin.

Williams, Raymond. 1974. Television - Technology and Cultural Form. London: Fontana.

Williams, Raymond. 1977. Marxism and Literature. Oxford: Oxford University Press.

Williams, Raymond. 1981. Marxism, Structuralism and Literary Analysis. New Left Review 129: 51-66.

Williams, Raymond. 2011 [1961]. The Long Revolution. Cardigan: Parthian.

Winston, Brian. 1995 [1990]. How are Media Born and Developed? In Questioning the Media - A Critical Introduction, ed. John Downing, Ali Mohammadi and Annabelle Sreberny-Mohammadi. 54-74. London: Sage.

Winston, Brian, 1996, Technologies of Seeing - Photography, Cinematography and Television. London: British Film Institute.

Wright, Erik Olin, 2010, Envisioning Real Utopias, London: Verso.

\section{About the Author}

Jim McGuigan

is Professor of Cultural Analysis in the Department of Social Sciences at Loughborough University, UK. His most recent books are Cool Capitalism (Pluto, 2009) and Cultural Analysis (Sage, 2010). 